MAREK PAWLAK

Katolicki Uniwersytet Lubelski Jana Pawła II, Polska - John Paul II Catholic University of Lublin, Poland

\title{
Uwarunkowania moralności przyszłych liderów biznesu z perspektywy deontologicznej
}

\section{Moral conditions of future business leaders from the deontological perspective}

\begin{abstract}
Streszczenie: Zaproponowano nową koncepcję badania poziomu rozwoju moralnego, opartą na połączeniu teorii rozwoju moralnego Kohlberga z teorią wartości Schwartza. Przeprowadzono badania, w których wzięło udział 1385 studentów zarządzania i kierunków pokrewnych z Polski, Bułgarii, Włoch, Tajwanu i Stanów Zjednoczonych. Badano dwa czynniki, które istotnie różnicują osoby z punktu widzenia rozwoju moralnego, mianowicie kraj pochodzenia i deklarowany poziom religijności. Z badań wynika, że studenci z krajów Europy Środkowowschodniej mają niższy współczynnik rozwoju moralnego niż osoby z krajów rozwiniętych. Ponadto osoby deklarujące wyższą religijność mają wyższy współczynnik rozwoju moralnego niż osoby deklarujące niższą religijność. Jednocześnie nie stwierdzono różnic poziomu rozwoju moralnego pomiędzy osobami deklarującymi, że są religijne a osobami deklarującymi, że nie są religijne.
\end{abstract}

\begin{abstract}
A new concept for the study of the level of moral development was proposed, based on a combination of Kohlberg's moral development theory and Schwartz's value theory. The study involved 1,385 students of management and related fields from Poland, Bulgaria, Italy, Taiwan and the United States. Two factors have been studied that significantly differentiate individuals from the point of view of moral development, namely the country of origin and the declared level of religiosity. Research shows that students from Central and Eastern European countries are at a lower level of moral development than those from developed countries. In addition, people who declare a higher religiosity are at a higher level of moral development than those who declare lower religiosity. At the same time, there were no differences in the level of moral development between those who declare themselves religious and those who declare that they are not religious.
\end{abstract}

Słowa kluczowe: religijność; rozwój moralny; studenci zarządzania; teoria Kohlberga; teoria Schwartza

Keywords: Kohlberg theory; management students; moral development; religiosity; Schwartz theory 
Otrzymano: 11 maja 2021

Received: 11 May 2021

Zaakceptowano: 23 sierpnia 2021

Accepted: 23 August 2021

Sugerowana cytacja/Suggested citation:

Pawlak, M. (2021). Uwarunkowania moralności przyszłych liderów biznesu z perspektywy deontologicznej. Przedsiębiorczość - Edukacja [Entrepreneurship - Education], 17(2), 51-67. https://doi. org/10.24917/20833296.172.4

\section{Wstęp}

Każdy wzrost lub rozwój oznacza przesuwanie się od niższego szczebla egzystencji do wyższego szczebla, bardziej preferowanego zgodnie z ideami i aspiracjami określonej grupy ludzi. Idee te wynikają z kultury, która reprezentuje najgłębsze założenia i przekonania o naturze człowieka, świata i celach życia (Mulla, Krishnan, 2014). Rozwój moralny jest jedną z determinant zachowań człowieka i przypisuje mu się coraz większe znaczenie w świecie biznesu. W typowych podręcznikach z zakresu zarządzania pojawiają się rozdziały poświęcone etyce, w programach studiów przewidziany jest taki przedmiot. Sygnały ze strony przyszłych pracodawców wskazują, że chcą oni zatrudniać osoby o wysokim poziomie rozwoju moralnego. Według Graduate Management Admission Council (2005), przedsiębiorstwa poszukują absolwentów studiów, którzy się takim rozwojem charakteryzują, a swoją szansę na zatrudnianie takich osób zwiększają dzięki praktykom rekrutacyjnym, weryfikacji i ocenie potencjalnych pracowników (Traiser, Eighmy, 2011).

Przykładowo P.M. Christie i wsp. (2003) ustalili, że większość menadżerów, badanych respondentów ze Stanów Zjednoczonych, Indii i Korei Południowej, zgadza się z twierdzeniem, że działalność biznesowa musi być prowadzona w sposób etyczny, aby wspierać długoterminowy sukces i rentowność: zachowanie etyczne i osiąganie zysków nie wykluczają się nawzajem. Można osiągać zyski również wtedy, gdy zachowujemy się w sposób etyczny. Natomiast zachowanie nieetyczne jest kosztowne dla firm, ich pracowników i inwestorów (Conroy, Emerson, 2004).

\section{Deontologiczne i utylitarystyczne teorie moralności}

Według Stanford Encyclopedia of Philosophy, we współczesnej filozofii moralnej deontologia jest teorią normatywną wyjaśniającą, które wybory są moralnie wymagane, zakazane lub dozwolone. Innymi słowy jest teorią moralną oceniającą nasze wybory i określającą, co powinniśmy robić. Deontologiczna koncepcja moralności zakłada, że określone działania są samoistnie dobre lub złe, niezależnie od tego, do jakich konsekwencji prowadzą (np. kłamstwo jest czymś złym) i że moralność jest definiowana poprzez takie działania (Aron, 1977). Na przykład w praktyce zarządzania tworzone są kodeksy etyki zawodowej (kodeksy deontologiczne), które są nie tylko zbiorem norm i akceptowanych zachowań moralnych, lecz również źródłem ich poznania (Kudlińska-Wodo, 2019).

W podejściu utylitarystycznym (teleologicznym, opierającym się na konsekwencjach) podstawą oceny, czy dany czyn jest moralny, są jego skutki. Oznacza to, że zawsze powinniśmy robić to, co będzie miało lepsze skutki, będzie bardziej użyteczne (Jackson, 1999: 141), stąd też nazwa tego podejścia. Zatem kłamstwo może być czymś dobrym, 
jeśli spowoduje pozytywny skutek. Na przykład tzw. kłamstwo obronne w stosunku do wroga, który chce wydobyć z nas określone informacje, aby nam zaszkodzić (Ossowska, 1985: 115).

W badaniach opisanych w niniejszym artykule wykorzystano koncepcję deontologiczną, która wywodzi się od I. Kanta (Aron, 1977).

\section{Moralność według Kanta}

W roku 1788 Kant opublikował książkę pt. Krytyka praktycznego rozumu, w której określił m.in. różne „Praktyczne materialne motywy determinujące pryncypium moralności"l (rycina 1).

Przykładowo wśród zasad subiektywnych zewnętrznych jest zasada ustroju społecznego opisana (reprezentowana) przez B. Mandeville’a. Jak napisał B. Bornstein, Mandeville przyjmuje „stanowisko naturalistyczne i broni wartości egoistycznych motywów postępowania człowieka (chciwości, zazdrości, ambicji itp.) jako jedynie sprzyjających rozwojowi kultury" (Kant, 2004). Według Mandeville’a, człowiek po nasyceniu głodu i apetytów seksualnych myśli przede wszystkim o pierwszeństwie i dominowaniu. „Jest on zwierzęciem niezwykle samolubnym i upartym, jak również chytrym [...] elementarne zasady moralności wprowadzone przez zręcznych polityków po to, ażeby uczynić ludzi pożytecznymi dla siebie wzajem oraz sfornymi, wymyślone zostały głównie w tym celu, aby ludzie ambitni mogli tym łatwiej i bezpieczniej rządzić licznymi rzeszami i ciągnąc z nich korzyści” (Mandeville, 1957: 35).

Z kolei według Crusiusa „podstawą moralnego obowiązku jest posłuszeństwo woli boskiej” (Kant, 2004). M. de Montaigne widział źródło grzechu w zarozumiałości, pochodzącej z urojonej wiedzy, prawdziwą zaś cnotę w posłuszeństwie nakazom wyższym. F. Hutcheson bronił poglądu, że „człowiek nie jest tylko istotą egoistyczną, kierującą się tylko własnym interesem, lecz że posiada także wrodzony zmysł dobra, zmysł moralny" (Kant, 2004). Uczucie moralne pozwala człowiekowi odróżnić czyny dobre od złych i doświadczać radości przy spełnianiu tych pierwszych. Zdaniem Wolffa, etyczne postępowanie musi opierać się na poznaniu natury doskonałości (harmonijnego rozwoju natury ludzkiej) i ma za cel doskonalenie się połączone z poczuciem szczęśliwości, które jest odbiciem przedmiotowego stanu doskonałości. Według stoików „cnota moralna była pewnym bohaterstwem mędrca, wznoszącego się ponad ludzką zwierzęcą naturę" (Kant, 2002: 217).

Na tle przedstawionej klasyfikacji Kant zaproponował coś nowego. Według niego prawo moralne ugruntowane jest $\mathrm{w}$ istocie naszego rozumu, wypływa $\mathrm{z}$ naszej świadomości moralnej, a nie jest nam z zewnątrz narzucone. My sami sobie ustanawiamy - według Kanta - naczelną zasadę moralności, wyznaczającą kierunek naszej woli. Sankcji prawa moralnego nie szukamy na zewnątrz siebie, lecz w głębi naszego ducha. Lecz pamiętać trzeba, że Kant nie ma tu na myśli empirycznego osobnika, osoby podlegającej zmiennym wciąż skłonnościom i popędom, lecz „lepszego człowieka”, który tkwi w każdym

\footnotetext{
${ }^{1}$ Jest to tłumaczenie J. Gałeckiego z roku 1984 (Warszawa: Państwowe Wydawnictwo Naukowe). W tłumaczeniu B. Bornsteina z roku 1910 fragment ten brzmi następująco: „Praktyczne materialne wyznaczniki w naczelnej zasadzie moralności”. W oryginale niemieckim: „Praktische materiale Bestimmungsgründe im Princip der Sittlichkeit”, w tłumaczeniu na język angielski, które przygotował T.K. Abbott: „Practical Material Principles of Determination taken as the Foundation of Morality".
} 


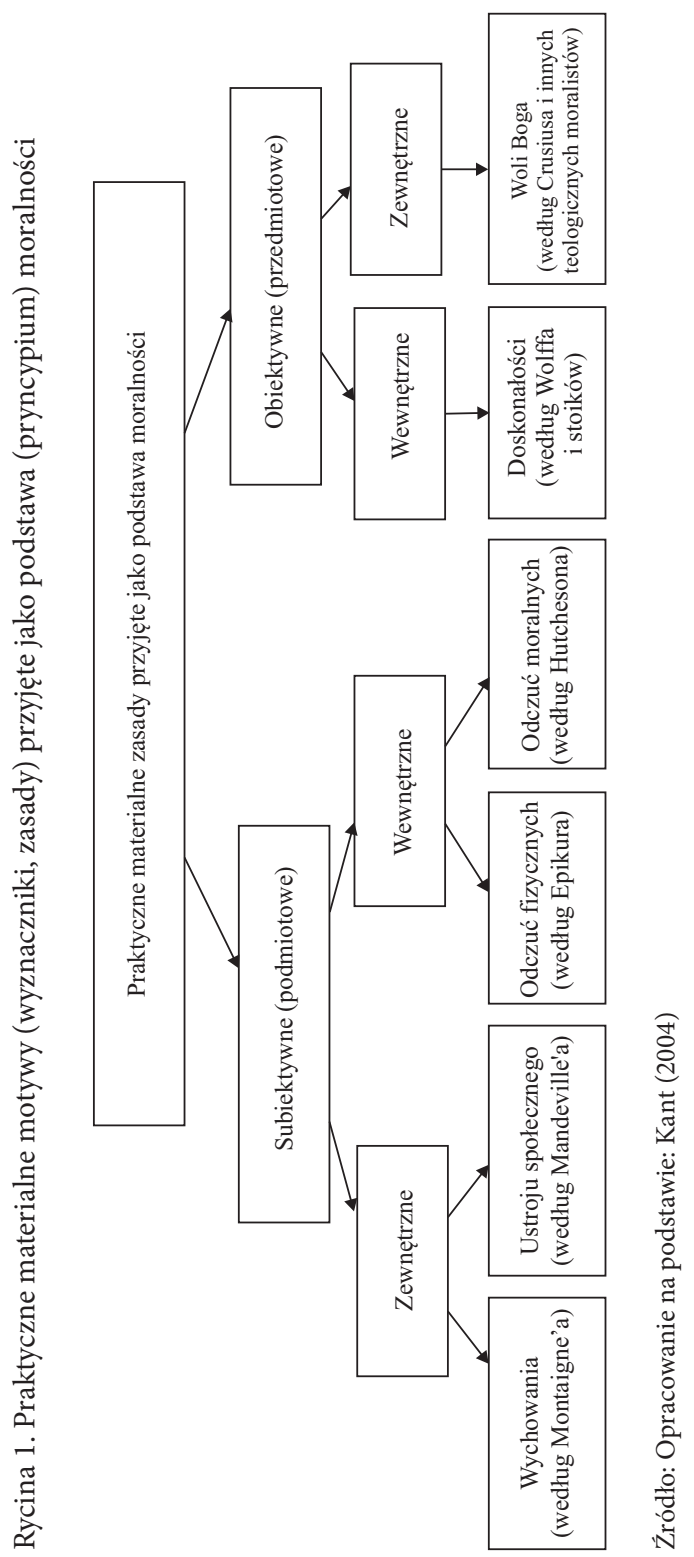


z nas. Do podobnych wniosków doszedł prawie 200 lat później L. Kohlberg, gdy budował swoją teorię i na postawie badań empirycznych identyfikował najwyższy szczebel rozwoju moralnego.

\section{Teoria Kohlberga}

Teoria Kohlberga jest chyba najbardziej znaną, wykorzystującą deontologiczną perspektywę teorią opisującą rozwój moralny człowieka. Ponieważ kształtowała się ona przez wiele lat i ulegała modyfikacjom także ze strony autora, w celu lepszego zrozumienia należy sięgnąć do jej pierwszych opisów. Wydaje się, że pierwsza publikacja Kohlberga na ten temat pochodzi z roku 1963 (Kohlberg, 1963). Jednym z prowadzonych wtedy przez niego badań była empiryczna identyfikacja następujących po sobie etapów rozwoju moralnego myślenia. Warto przypomnieć, że badania były prowadzone wśród 72 chłopców w wieku 10, 13 i 16 lat mieszkających w okolicach Chicago. Jak Kohlberg wyraźnie zaznacza, inspirował się na wcześniejszych analizach Piageta (1965). Z osobami badanymi przeprowadzano dwugodzinne wywiady i nagrywano je na magnetofonie. Nie stosowano wystandaryzowanych sposobów klasyfikacji badanych osób - przypisywania ich do typów zachowań. Na podstawie przeprowadzonych wywiadów stworzono trzy poziomy i sześć różnych typów zorientowania na wartości. Były to:

- Poziom I. Przedmoralny

- Typ1. Orientacja na karę i posłuszeństwo

- Typ 2. Naiwny instrumentalny hedonizm

- Poziom II. Moralność konwencjonalnej roli - konformizmu

- Typ 3. Moralność dobrego chłopca, utrzymywania dobrych relacji, aprobaty innych

- Typ 4. Moralność podporządkowania się autorytetom

- Poziom III. Moralność samodzielnie akceptowanych zasad moralnych

- Typ 5. Moralność kontraktu i demokratycznie zaakceptowanych praw

- Typ 6. Moralność indywidualnych zasad sumienia

Należy podkreślić, że te typy zorientowania na wartości nie były identyfikowane na podstawie badania hierarchii wartości, ale na podstawie identyfikowania procesów moralnego wnioskowania. Stąd też później teorię Kohlberga zaczęto określać mianem teorii wnioskowania moralnego, a typy zorientowania na wartości zaczęto określać mianem etapów wnioskowania moralnego (moral reasoning stages).

Jak pisze Kohlberg w swojej publikacji z roku 1963, w badaniach uwzględniono 30 różnych aspektów moralności, które badani chłopcy uwzględniali w swoim myśleniu. Tymi aspektami były przykładowo: pojęcie dobra, zorientowanie na „karzącą sprawiedliwość”, branie pod uwagę intencji w relacji do konsekwencji działań. Każdy aspekt był ujmowany w skali sześciostopniowej, a każdy punkt skali odpowiadał jednemu z 6 wymienionych typów moralności.

Przypisanie każdego z 72 badanych chłopców do określonego typu nie było „ostre”. Przykładowo, jak pisze Kohlberg, 15 chłopców zostało przypisanych do pierwszego typu, ponieważ $45 \%$ ich myślenia mogło być scharakteryzowane jako typ 1 . Należy także zauważyć, że Kohlberg używa tu wyrażenia „typy zorientowania na wartości”, później w swoich publikacjach używa już sformułowania moral development stages, czyli „etapy rozwoju moralnego". 
Późniejsze modyfikacje modelu Kohlberga

W kolejnych latach w wyniku dalszych badań Kohlberg zaczął budować teorię i wprowadzać modyfikacje do stwierdzeń zawartych w publikacji z roku 1963. Modyfikacje te można opisać następująco:

1. O ile na początku swoich prac Kohlberg opisywał wyniki badań empirycznych dzieci (Kohlberg, 1963, 1975; Kohlberg, Gilligan, 1971; Tapp, Kohlberg, 1971), o tyle później uogólnił swoją teorię i objął nią także osoby dorosłe (Haan, Langer, Kohlberg, 1976; Kohlberg, Elfenbein, 1975).

2. Na początku Kohlberg opisywał wyniki badań empirycznych i formułował pewne wnioski (Kohlberg, 1963), później zaczął budować teorię, którą nazywał różnie developmental theory (Kohlberg, Elfenbein, 1975), cognitive-developmental theory (Kohlberg, 1975), moral development theory (Kohlberg, Hersh, 1976; Tapp, Kohlberg, 1971).

3. Na początku Kohlberg mówił o „typach zorientowania na wartości”, nie wartościując, które typy są lepsze, a które gorsze. Później mówił o „etapach rozwoju moralnego”, wyraźnie wskazując, że człowiek, rozwijając się, przechodzi od niższych do wyższych etapów rozwoju.

4. W swoich badaniach Kohlberg używał przykładów dylematów moralnych i dyskutował na ich temat $z$ dziećmi. Na początku były to rozmowy nagrywane na magnetofonie i trwające około dwóch godzin (Kohlberg, 1963), później podjęto próbę standaryzacji procedury badań i stworzono Moral Judgment Interview - MJI (Elm, Weber, 1994; Weber, 1996).

\section{Podejście Resta}

Jednym z ważnych ograniczeń podejścia Kohlberga była procedura identyfikowania etapu rozwoju moralnego określonej osoby - wywiady wymagały wiele czasu i zaangażowania doświadczonych badaczy. Chyba głównie dlatego powstało podejście J. Resta (Rest et al., 1999), będące modyfikacją teorii Kohlberga. W podejściu tym wykorzystywane są kwestionariusze ankiet (test DIT), umożliwiające badanie dużej liczby osób ze stosunkowo małym zaangażowaniem ze strony badającego, dzięki czemu badania mogą prowadzić także osoby bez specjalnych kwalifikacji.

Współcześnie do oceny poziomu rozwoju moralnego badanych osób wykorzystywane jest głównie podejście Resta. Istnieją gotowe ankiety i ustalone procedury umożliwiające badanie np. pracowników w organizacjach, studentów na uczelniach. Dzięki nim można porównywać osoby z różnych kręgów kulturowych, osoby religijne z ateistami czy kobiety z mężczyznami.

Podejście Resta nie pozwala jednak na identyfikowanie etapu rozwoju moralnego badanych osób. Umożliwia jedynie porównanie, czy rozwój moralny danej osoby (lub grupy osób) jest wyższy lub niższy od rozwoju moralnego innej osoby. Używany jest do tego celu współczynnik $P$, który jest obliczany jako procent gotowości badanej osoby do użycia piątego lub szóstego poziomu wnioskowania moralnego (Robin et al., 1996).

W ostatnich latach pojawiło się jednak wiele uwag krytycznych na temat podejścia Resta. Według A.D. Blay’a i wsp.: „coraz większa liczba badaczy postrzega DIT jako wadliwy miernik poziomu moralnego rozumowania” (Blay et al., 2018: 197). D.G. Fisher i J.T. Sweeney wskazują, że „DIT w dużej mierze rejestruje relatywizm badanej osoby i jej 
liberalne poglądy polityczne" (Fisher, Sweeney, 1998: 905). Z kolei zdaniem Bailey’a i wsp. „DIT stracił swoją użyteczność lub, co gorsza, okazał się wadliwą miarą oceny etycznej” (Bailey et al., 2010: 1). Wyniki uzyskane przez Fishera i Sweeneya (1998) wskazują również, że na rezultaty uzyskane za pomocą DIT może wpływać aspekt ideologii politycznej, który nie odzwierciedla dojrzałości oceny moralnej. Badani obniżyli swoje oceny moralne, odpowiadając na dylematy DIT z perspektywy konserwatywnej. W przeciwieństwie do teorii rozwoju moralnego, badani byli w stanie zwiększyć swoje oceny moralne, odpowiadając z perspektywy politycznego liberała (Fisher, Sweeney, 1998).

\section{Teoria Schwartza}

Inną teorią jest teoria S.H. Schwartza. Badacz ten wyróżnił 56 wartości i podzielił je na dwie kategorie: wartości terminalne (30 elementów) i wartości instrumentalne (26 elementów). Następnie przy wykorzystaniu metody skalowania wielowymiarowego stworzył 10 typów wartości i nadał im następujące nazwy: decydowanie o sobie, stymulacja, hedonizm, osiągnięcia, władza, bezpieczeństwo, konformizm, tradycja, życzliwość i uniwersalizm. Weryfikacja praktyczna tego modelu odbyła się w wielu krajach za pomocą licznych badań ankietowych. Jak podają A. Perrinjaquet i inni (2007), struktura i skład system wartości Schwartza zostały potwierdzone empirycznie na podstawie ponad 200 badań ankietowych przeprowadzonych w ponad $60 \mathrm{krajach}$.

$\mathrm{Na}$ podstawie modelu Schwartza opracowano kilka narzędzi do pomiaru wartości. Pierwszym z nich był kwestionariusz Schwartza określany mianem Schwartz Value Survey (SVS). Kwestionariusz ten zawiera dwie listy 30 i 26 pozycji wartości. Każda pozycja odzwierciedla jakiś aspekt motywacyjnego celu określonej wartości. Respondenci oceniają ważność każdej pozycji za pomocą dziewięciopunktowej skali od -1 do 7 (Struch, Schwartz, van der Kloot, 2002). Jak podaje Schwartz (2006), kwestionariusz SVS został przetłumaczony na 47 języków.

Drugim, opracowanym później, narzędziem jest tak zwany kwestionariusz portretów wartości - Portrait Values Questionnaire (PVQ). Jak podaje Schwartz (2006: 13), został on „opracowany w celu pomiaru dziesięciu podstawowych typów wartości w grupach dzieci starszych niż 11 lat, wśród ludzi w podeszłym wieku i wśród ludzi, którzy nie ukończyli szkół w krajach zachodnich, które w procesach edukacyjnych zwracają dużą uwagę na myślenie abstrakcyjne” (Schwartz, 2006: 13). Przyjęto tu założenie, że „kwestionariusz SVS jest w sensie poznawczym zbyt skomplikowany i zbyt abstrakcyjny dla ludzi młodych" (Liem et al., 2011: 146-147).

Trzecim narzędziem jest tak zwany European Social Survey Questionaire (ESSQ). Zawiera on 21 opisów portretów z kwestionariusza PVQ. Niektóre z portretów zostały tu poprawione, aby lepiej odzwierciedlić zawartość modelu dziesięciu podstawowych wartości (Knoppen, Saris, 2009). Kwestionariusz ESSQ tak samo jak kwestionariusz PVQ wykorzystuje sześciopunktową skalę odpowiedzi.

\section{Pomiar poziomu rozwoju moralnego na podstawie hierarchii wartości}

W opisywanym w niniejszym artykule nowym podejściu do pomiaru poziomu rozwoju moralnego zaproponowano połączenie teorii Kohlberga z teorią Schwartza. Przypisano wartości i typy wartości Schwartza do poziomów rozwoju moralnego Kohlberga. Przedstawiono to w tabeli 1. 


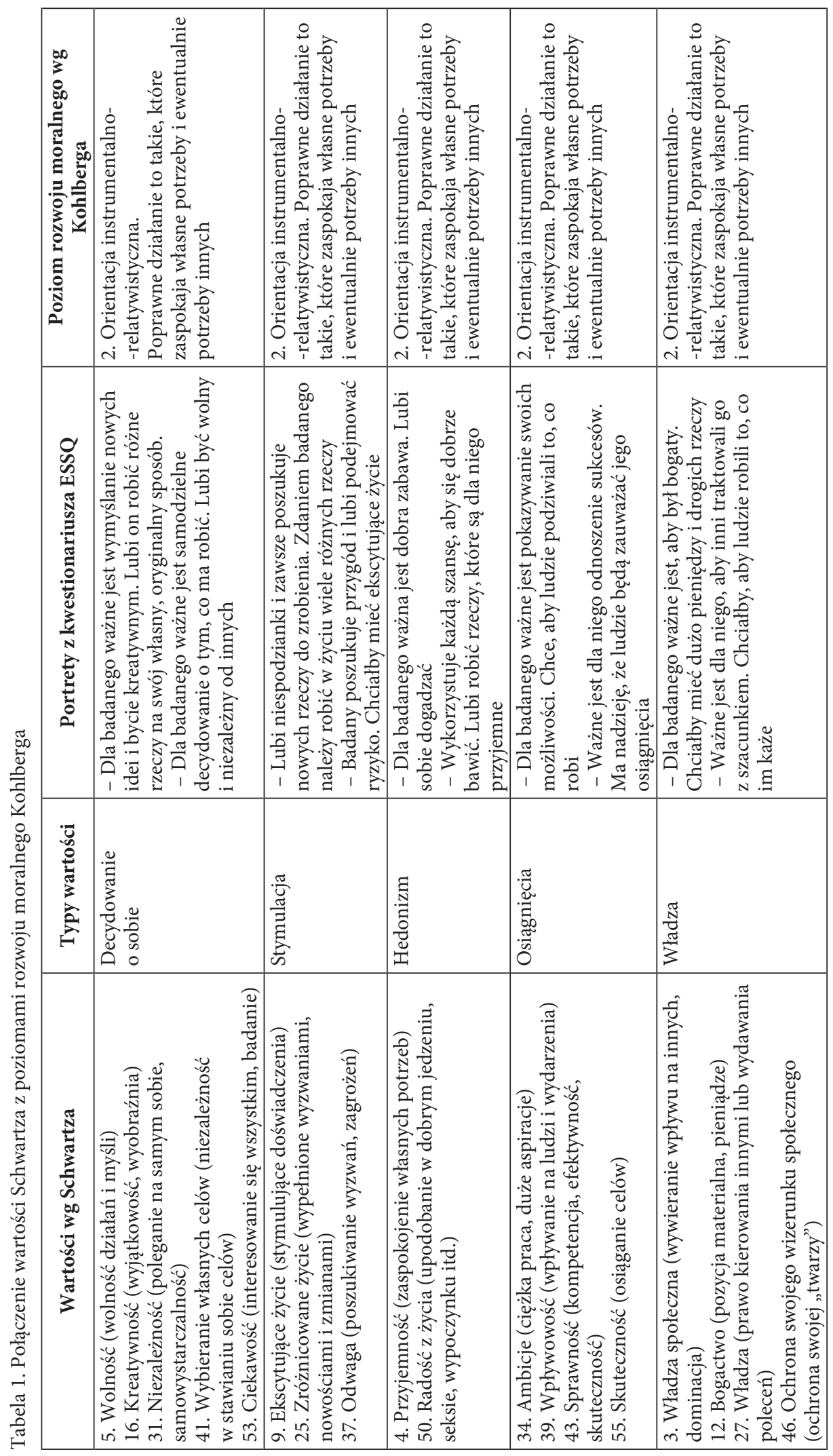




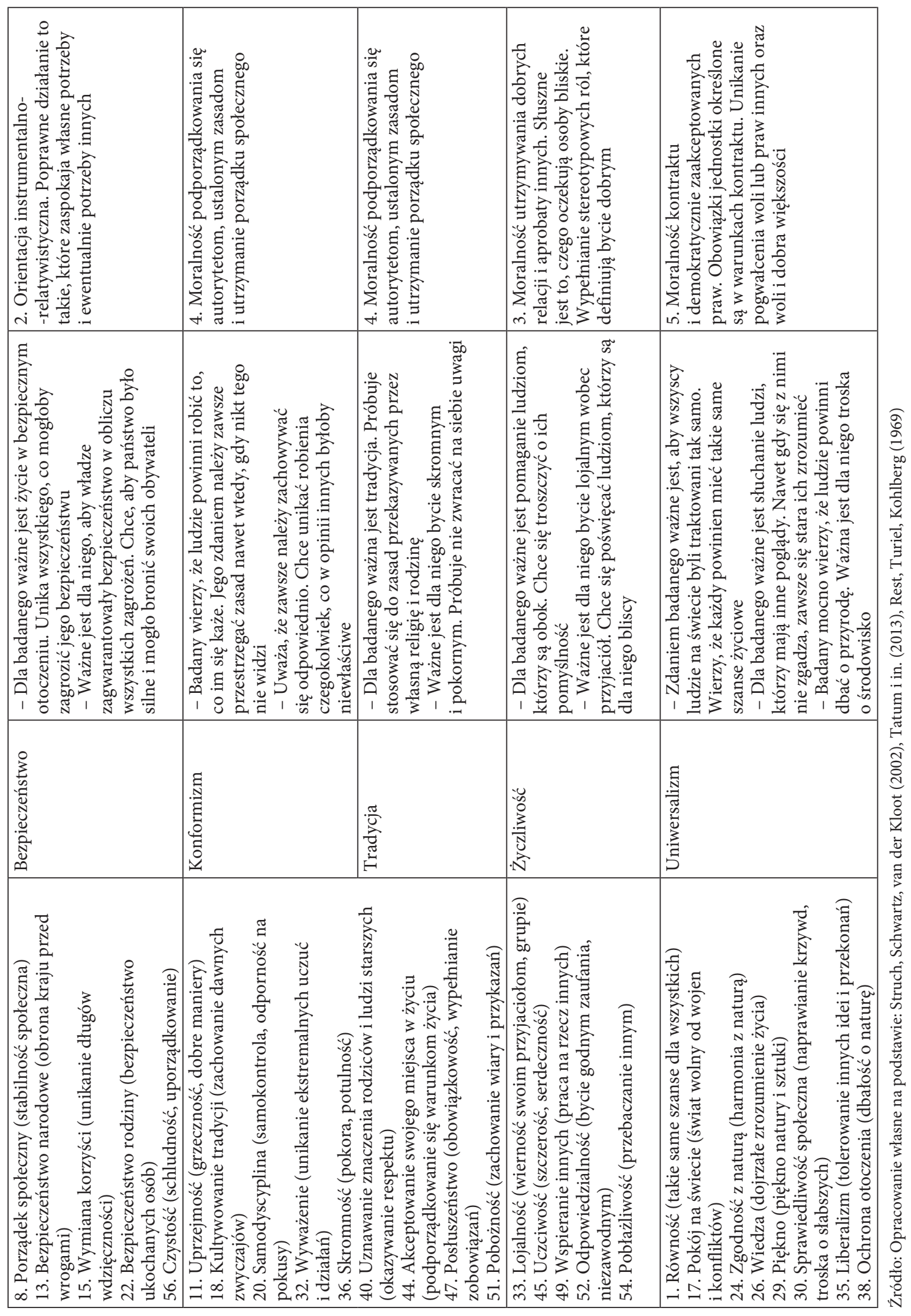


Dzięki takiemu podejściu można było wykorzystać kwestionariusz ESSQ do przypisania osoby do określonego poziomu rozwoju moralnego. W tabeli 1 nie uwzględniono poziomu 1, ponieważ wartości zdefiniowane przez Schwartza nie uwzględniają zachować należących do pierwszego poziomu rozwoju moralnego charakterystycznego raczej dla małych dzieci, a Schwartz w swoich badaniach był nastawiony na osoby dorosłe. Nie uwzględniono także poziomu 6, co do którego niektórzy badacze uważają, że jest on raczej konstrukcją teoretyczną, trudną do weryfikacji empirycznej.

\section{Indeks rozwoju moralnego}

Według Kohlberga, człowiek nie może być przypisany do jednego poziomu rozwoju moralnego, jego rozumowanie zawiera raczej w pewnym stopniu cechy różnych poziomów. W związku z tym zaproponowano zastosowanie indeksu MDI (Moral Development Index), uwzględniającego różne poziomy i większą wagę poziomów wyższych (Payne, Pawlak, Mahesh, 2018):

$$
\mathrm{MDI}=3\left(\mathrm{r}_{5}-\mathrm{r}_{2}\right)+2\left(\mathrm{r}_{5}-\mathrm{r}_{3}\right)+\left(\mathrm{r}_{5}-\mathrm{r}_{4}\right)+2\left(\mathrm{r}_{4}-\mathrm{r}_{2}\right)+\left(\mathrm{r}_{4}-\mathrm{r}_{3}\right)+\left(\mathrm{r}_{3}-\mathrm{r}_{2}\right)
$$

gdzie:

$r_{\mathrm{i}}=$ średnia akceptacja określonego etap rozwoju moralnego $i$ na podstawie kwestionariusza ESSQ. Należy zauważyć, że średnia uwzględnia zróżnicowaną liczbę „portretów” w ESSQ do oceny każdego etapu (12, 2, 4 i 3).

\section{Sformułowanie hipotez badawczych}

\section{Uwarunkowania kulturowe}

J. Jackson (1999) uważa, że różnice w postawach etycznych na poziomie krajowym „można przypisać różnicom w podstawowych wartościach kulturowych”. Jego badanie wykazało, że „postawy etyczne różnią się między grupami narodowymi” (Jackson, 1999).

Ponieważ „kultura ma silny wpływ na postawy etyczne menadżerów” (Christie et al., 2003: 279), nie można oddzielić kultury od etyki. Etyka jest zakorzeniona w kulturze, a kultura jest ukształtowana przez przekonania etyczne, wartości, postawy i zachowania (Jackson, 1999).

Christie i wsp. sugerują, że „kultura wpływa na etyczną percepcję, postawę i zachowanie” i dostarcza listę źródeł, które potwierdzają teorię, że istnieją „istotne różnice we wpływie kultury na postrzeganie etycznych postaw i zachowań oraz sposób, w jaki ludzie postrzegają problemy etyczne" (Christie et al., 2003).

W literaturze dotyczącej etyki biznesu wskazuje się na fakt, że ustrój komunistyczny, który był obecny w Polsce przez ponad 45 lat, miał istotny wpływ na system wartości, postawy i zachowania mieszkańców tej części Europy. Używa się tu nawet nazwy „kraje postkomunistyczne".

L.E. Brouthers, D.N. Lascu i S. Werner (2008: 399) opisujący sytuację na Słowacji i w Chinach twierdzą, że odejście komunistów pozostawiło „próżnię moralną”. Wynikała ona częściowo z niedoskonałości postkomunistycznego systemu prawnego. Nie było tu solidnej bazy w postaci zachodniego porządku społecznego, jego struktury lub zasad. 
Brouthers, Lascu i Werner uważają ponadto, że „ta próżnia moralna została wypełniona dość bezwzględną i konkurencyjną formą kapitalizmu, taką, w której wartości niematerialne, takie jak prawa autorskie i patenty, nie są chronione, gdzie inwestorzy mają niewielką ochronę prawną, gdzie klienci są rutynowo poddawani oszustwom w biznesie i gdzie korupcja jest wszechobecna" (Brouthers, Lascu i Werner, 2008: 405).

Próżnia moralna, która powstała po odejściu komunistów, stworzyła dwie kategorie menadżerów. (1) „doświadczonych wcześniejszych komunistów, których wiedza może nie prowadzić do efektywności, ale którzy są racjonalni w ramach swojego systemu poglądów” i „młodych, świeckich, bezwzględnych menadżerów, którzy prowadzą politykę walki z konkurentami w celu osiągnięcia własnych maksymalnych zysków" (Brouthers, Lascu, Werner, 2008).

C. Stoian i R.M. Zaharia uważają z kolei, że proces zmniejszania instytucjonalnych różnic pomiędzy gospodarką zachodnią a gospodarką postkomunistyczną „jest utrudniany przez wewnętrzny opór zakorzenionych zwyczajów i praktyk, które są akceptowane jako uprawnione i które są rutynowo powtarzane przez ekonomicznych aktorów" (Stoian, Zaharia, 2012: 386).

Na podstawie tych literaturowych studiów można sformułować pierwszą hipotezę badawczą:

H1: Rozwój moralny przyszłych menadżerów ma związek z krajem pochodzenia i tym samym ze środowiskiem kulturowym.

\section{Uwarunkowania religijne}

W badania dotyczących rozwoju moralnego wielokrotnie wskazywano na uwarunkowania związane z religią. Ujmując rzecz ogólnie, B. Ramasamy wraz ze wsp. pisze, że religijność stanowi tło dla oceny etycznej i wpływa na postawę i zachowanie (Ramasamy et al., 2010). J.M. Day (2017) ujmuje to dość jednoznacznie i twierdzi, że przynależność religijna, wiara i jej praktykowanie są często skorelowane z postawami prospołecznymi, takimi jak empatia, ogólna troska o innych, wolontariat, docenianie życzliwości i gotowość do pomagania innym w niebezpieczeństwie, co można postrzegać jako cechy wysokiego rozwoju moralnego w kategoriach Kohlberga.

Wielokrotnie badano rozwój moralny osób religijnych i tu wyniki nie były jednoznaczne. Przeprowadzano także badania z wykorzystaniem testu DIT i, jak pisze B.M. Sabin (2006), często okazywało się, że osoby deklarujące, że są chrześcijanami, uzyskiwały wynik na poziomie średniej krajowej, jednak wiele innych badań wykazało, że chrześcijanie uzyskiwali wynik poniżej średniej. J.L. Tatum i jego współpracownicy (2013) badali związek między przynależnością religijną uczniów pierwszego roku college'u a ich rozwojem moralnym za pomocą testu DIT. Uzyskane przez nich wyniki wskazują, że osoby, które nie deklarowały żadnych preferencji religijnych, miały znacznie wyższe wyniki $P(M=45,2)$ niż osoby, które zidentyfikowały się jako katolicy $(M=36,1)$ lub protestanci $(M=38,6)$.

Te dyskusyjne wyniki mogą wynikać z faktu, że test DIT nie jest idealnym narzędziem do oceny poziomu wnioskowania moralnego, przez co jest ostatnio dość często krytykowany (Bailey et al., 2010; Blay et al., 2018; Fisher, Sweeney, 1998).

Biorąc pod uwagę te zróżnicowane opinie na temat związku rozwoju moralnego z moralnością, można sformułować hipotezę drugą:

H2: Rozwój moralny przyszłych menadżerów ma związek z ich religijnością. 
Wyniki badań

Badania, których celem była weryfikacja sformułowanych tu hipotez, przeprowadzono wśród 1385 studentów zarządzania i kierunków pokrewnych w pięciu krajach: Polska, Bułgaria, Taiwan, Włochy i USA.

\section{Weryfikacja hipotezy pierwszej}

Na podstawie uzyskanych wyników można stwierdzić, że studenci pochodzący z różnych krajów różnią się istotnie (ANOVA, $F=7,612, p<0,001$ ) z punktu widzenia rozwoju moralnego - osoby z krajów Europy Środkowowschodniej (Polska i Bułgaria) mają istotnie niższy współczynnik rozwoju moralnego niż studenci z krajów rozwiniętych. Co ciekawe, prawie nie odnotowano różnic w poziomie rozwoju moralnego studentów z Włoch, Tajwanu i USA, chociaż państwa te leżą na różnych kontynentach (rycina 2).

\section{Weryfikacja hipotezy drugiej}

Także deklarowany poziom religijności różnicował istotnie badanych studentów z punktu widzenia indeksu moralności (ANOVA, $F=5,443, p=0,001$ ). Wyniki przedstawiono na rycinie 3.

Na podstawie wyników badań można stwierdzić, że wraz ze wzrostem poziomu religijności rośnie wartość indeksu rozwoju moralnego. Jednocześnie nie stwierdzono istotnych różnic pomiędzy osobami, które deklarują, że są ateistami, a osobami deklarującymi, że są religijne $(t=0,036, p=0,971)$.

Rycina. 2. Indeks rozwoju moralnego a kraj pochodzenia

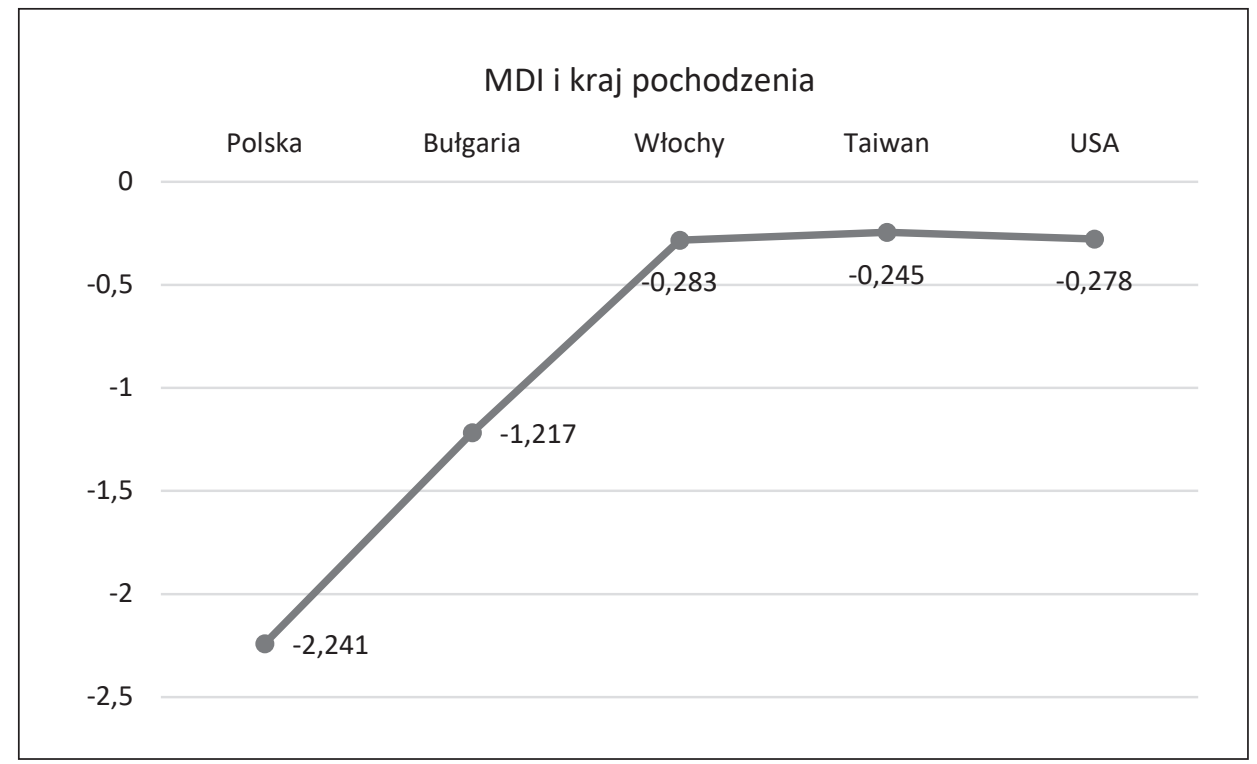

Źródło: Opracowanie własne 
Rycina 3. Indeks rozwoju moralnego a poziom religijności

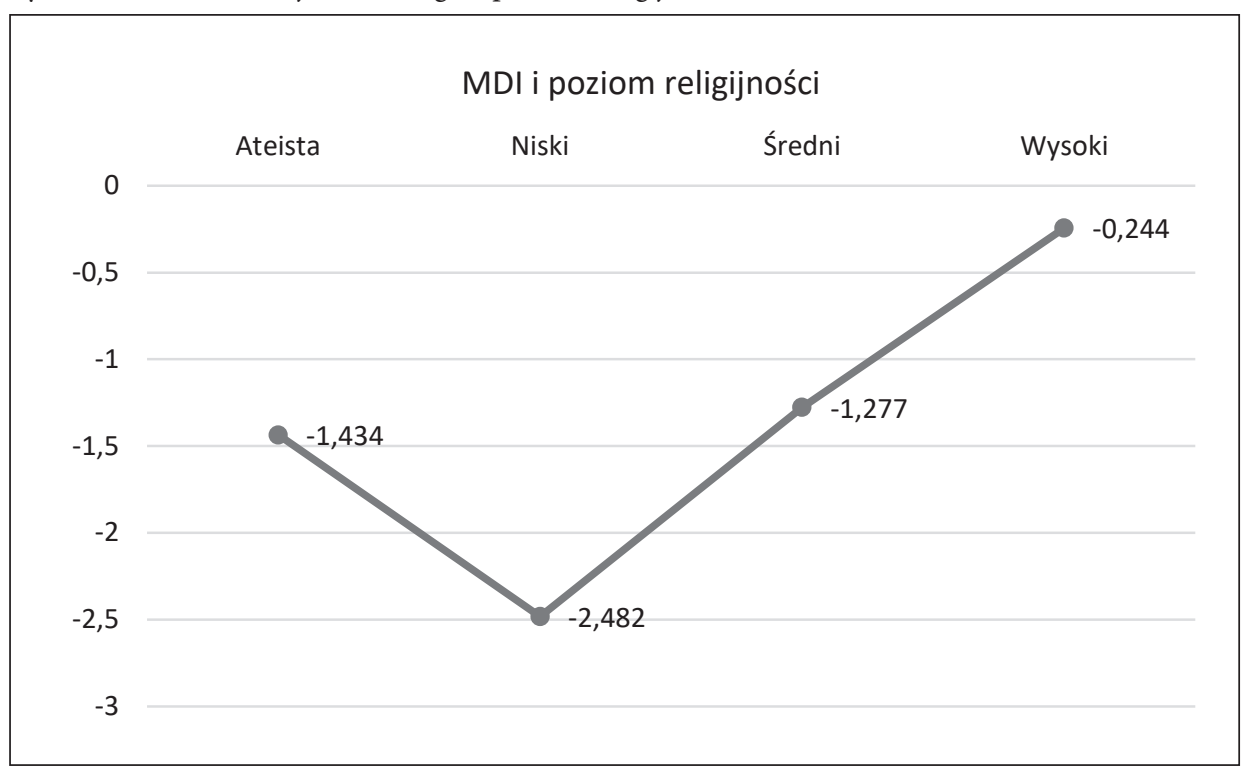

Źródło: Opracowanie własne

\section{Podsumowanie}

Wyniki badań przeprowadzonych na grupie 1385 studentów z pięciu krajów i trzech kontynentów z zastosowaniem opisanego tu podejścia wskazują, że występują istotne różnice systemów wartości i tym samym indeksu rozwoju moralnego pomiędzy studentami z krajów Europy Środkowowschodniej i krajów rozwiniętych. Można sądzić, że niższy poziom rozwoju moralnego osób z krajów Europy Środkowowschodniej jest swego rodzaju spuścizną 45 lat obecności komunizmu i pozostałości, których nie da się szybko zmienić.

Ponadto stwierdzono, że wraz ze wzrostem deklarowanego poziomu religijności rośnie poziom rozwoju moralnego. Jak to ujął M. Rokeach (1965), wszystkie religie zachodnie uczą członków swoich wspólnot wzajemnej miłości i szacunku, złotej zasady (golden rule), umiłowania sprawiedliwości i miłosierdzia, a także uważają wszystkich ludzi za równych w oczach Boga. Jest to z pewnością nawiązanie do szóstego typu rozwoju moralnego zidentyfikowanego empirycznie przez Kohlberga i postulowanego przez Kanta.

Uzyskane wyniki są także zgodne z poglądami Daya (2017), który we wnioskach z realizowanych przez wiele lat badań pisze, że wieloczynnikowa ocena obejmująca tysiące osób pochodzących z różnych kultur pokazała, że wiara, zaangażowanie religijne i przynależność do wspólnoty religijnej należą do najlepszych predyktorów satysfakcji z życia i dobrego samopoczucia w wieku dorosłym, poczucia osobistej skuteczności i kontroli, a także skutecznego radzenia sobie z przeciwnościami losu. Przynależność do wspólnoty religijnej, wiara i jej praktykowanie są często skorelowane z zachowaniami prospołecznymi, takimi jak empatia, troska o innych, wolontariat, życzliwość i chęć pomagania innym w potrzebie. Wiara i jej praktykowanie wspierają rozsądek, powiązany z udoskonalonym 
rozwiązywaniem problemów, traktowania spraw z dystansem, optymizmem, skromnością, wspaniałomyślnością, tolerancją i komunikacją z innymi.

\section{Ograniczenia zaproponowanego podejścia}

Na zakończenie warto wspomnieć o tym, że teoria Kohlberga, na której oparte były opisane badania, ma swoich zwolenników, a także wielu oponentów kwestionujących ją $\mathrm{z}$ różnych punktów widzenia. Jest ona określana mianem racjonalistycznej, ale w ostatnim czasie coraz więcej zwolenników zyskują teorie opierające się na emocjach (Haidt, 2001). C. Gilligan twierdzi, że inaczej na moralne dylematy stworzone przez Kohlberga reagują kobiety, a inaczej - mężczyźni (Gilligan, 1982: 24-39), E. Simpson (1974) uważa, że teoria Kohlberga opiera się na zachodniej tradycji filozoficznej i bez uzasadnienia zakłada, że jest ona ważna także w innych kulturach. Jest ona także krytykowana z perspektywy filozoficznej (Aron, 1977) i religijnej (Richards, 1991; Richards, Davidson, 1992).

Literatura

References

Aron, I.E. (1977). Moral Philosophy and Moral Education: A Critique of Kohlberg's Theory, The School Review, 85(2), 197-217.

Bailey, C.D., Scott, I., Thoma, S.J. (2010). Revitalizing Accounting Ethics Research in the NeoKohlbergian Framework: Putting the DIT into Perspective. Behavioral Research in Accounting, 22(2), 1-26. https://doi.org/10.2308/bria.2010.22.2.1

Blay, A.D., Gooden, E.S., Mellon, M.J., Stevens, D.E. (2018). The Usefulness of Social Norm Theory in Empirical Business Ethics Research: A Review and Suggestions for Future Researc. Journal of Business Ethics, 152, 191-206. https://doi.org/10.1007/s10551-016-3286-4

Brouthers, L.E., Lascu, D.N., Werner, S. (2008). Competitive Irrationality in Transitional Economies: Are Communist Managers Less Rational?. Journal of Business Ethics, 83, 397-405.

Christie, P.M.J., Kwon, I.W.G., Stoeberl, P.A., Baumhart, R. (2003). A Cross-Cultural Comparison of Ethical Attitudes of Business Managers: India, Korea and the United States. Journal of Business Ethics, 46, 263-287.

Conroy, S.J., Emerson, T.L.N. (2004). Business Ethics and Religion: Religiosity as a Predictor of Ethical Awareness among Students. Journal of Business Ethics, 50, 383-396.

Day, J.M. (2017). Religion and Human Development in Adulthood: Well-Being, Prosocial Behavior, and Religious and Spiritual Development. Behavioral Development Bulletin 22(2), 298-313.

Elm, D.R., Weber, J. (1994). Measuring Moral Judgment: The Moral Judgment Interview or the Defining Issues Test?. Journal of Business Ethics, 13, 341-355.

Fisher, D.G., Sweeney, J.T. (1998). The Relationship Between Political Attitudes and Moral Judgment: Examining the Validity of the Defining Issues Test. Journal of Business Ethics, 17, 905-916.

Gilligan, C. (1982). In a Different Voice Psychological Theory and Women's Development. Harvard University Press, Cambridge, Massachusetts.

Graduate Management Admission Council. (2005; 2021, 12 February). Application Trends Survey, Executive Summary of Key Findings. Retrieved from: https://www.gmac.com/market-intelligence-and-research/research-library/admissions-and-application-trends/2005-application-trends-survey-executive-summary-report

Haan, N., Langer, J., Kohlberg, L. (1976). Family Patterns of Moral Reasoning. Child Development, 47, 1204-1206. 
Haidt, J. (2001). The emotional dog and its rational tail: A social intuitionist approach to moral judgment. Psychological Review, 108, 814-834.

Jackson, J. (1999). Biznes i moralność. Warszawa: Wydawnictwo Naukowe PWN.

Kant, I. (2002). Krytyka praktycznego rozumu. Kęty: Wydawnictwo Antyk.

Kant, I. (2004). Krytyka praktycznego rozumu, przekład Benedykt Bornstein. Warszawa: De Agostini Spółka z o.o.

Knoppen, D., Saris, W. (2009). Evaluation of the Portrait Values Questionnaire using SEM: A New ESS Proposal. Paper prepared for the QMSS2 seminar at Bolzano (Bozen), Italy, June 11-12.

Kohlberg, L. (1975). Moral Education for a Society in Moral Transition. Educational Leadership, 33(1), 46-54.

Kohlberg, L. (1963). The Development of Children's Orientations Toward a Moral Order I. Sequence in the Development of Moral Thought. Vita Humana, 6, 11-33.

Kohlberg, L., Elfenbein, D. (1975). The Development of Moral Judgments Concerning Capital Punishment. American Journal of Orthopsychiatry, 45(4), 614-640.

Kohlberg, L., Gilligan, C. (1971). The Adolescent as a Philosopher: The Discovery of the Self in a Postconventional World. Twelve to Sixteen: Early Adolescence. Daedalus, 100(4), 1051-1086.

Kohlberg, L., Hersh, R.H. (1977). A Theory of Moral Development: A Review of the Theory. Theory into Practice, 16(5), 53-50.

Kudlińska-Wodo, B. (2019). Deontologia profesjonalnego działania w zawodach pomocowych w świetle analizy kodeksów etycznych. Acta Universitatis Lodzienzis, Folia Sociologica, 69, 91-106. http:// dx.doi.org/10.18778/0208-600X.69.06

Liem, G., Arief, D., Martin, A.J., Nair, E., Bernardo, A.B.I., Prasetya, P.H. (2011). Content and Structure of Values in Middle Adolescence: Evidence from Singapore, the Philippines, Indonesia, and Australia. Journal of Cross-Cultural Psychology, 42(1), 146-154. https://doi.org/10.1177/0022022110383309

Mandeville, B. (1957). Bajka o pszczołach. Warszawa: Państwowe Wydawnictwo Naukowe.

Mulla, Z.R., Krishnan, V.R. (2014). Karma-Yoga: The Indian Model of Moral Development. Journal of Business Ethics, 123, 339-351.

Ossowska, M. (1985). Normy moralne próba systematyzacji. Warszawa: Państwowe Wydawnictwo Naukowe.

Payne, D., Pawlak, M. and Mahesh, S. (2018). The Moral Development Index of Future Business Leaders: A Study on the Impact of Changes in Economic Systems and Gender. Journal of Business and Management, 24(1), 50-79.

Perrinjaquet, A., Radboud, O.F., Usunier, J.C., Cestre, G., Valette-Florence, P. (2007). A Test of the Quasi-Circumplex Structure of Human Values. Journal of Research in Personality, August 2007. https://doi.org/10.1016/j.jrp.2006.10.006

Piaget, J. (1965; 2021, 12 February). The Moral Judgment of the Child. Illinois: Free Press, Glencoe. Retrieved from: https://archive.org/details/moraljudgmentoft005613mbp/page/n5

Ramasamy, B., Yeung, M.C.H., Au, A.K.M. (2010). Consumer Support for Corporate Social Responsibility (CSR): The Role of Religion and Values. Journal of Business Ethics, 91, 61-72.

Rest, J., Turiel, E., Kohlberg, L. (1969). Level of Moral Development as a Determinant of Preference and Comprehension of Moral Judgments Made by Others. Journal of Personality, 37(2), 225-252.

Rest, J., Narvaez, D., Bebeau, M., Thoma, S. (1999). A Neo-Kohlbergian Approach: The DIT and Schema Theory. Educational Psychology Review, 11(4), 291-324.

Richards, S. (1991). The Relation between Conservative Religious Ideology and Principled Moral Reasoning: A Review. Review of Religious Research, 32(4), 359-368.

Richards, S., Davison, M. (1992). Religious Bias in Moral Development Research: A Psychometric Investigation. Journal for the Scientific Study of Religion, 31(4), 467-485.

Robin, D.P., Gordon, G., Jordan, C., Reidenbach, R.E. (1996). The Empirical Performance of Cognitive Moral Development in Predicting Behavioral Intent. Business Ethics Quarterly, 6(4), 493-515. 
Rokeach, M. (1965). Paradoxes of religious belief. Trans-Action, 2, 9-12. https://doi.org/10.1007/ BF03180791

Sabin, B.M. (2006). A Faith-Based Program Evaluation: Moral Development of Seminary Students at the Louisiana State Penitentiary. A dissertation submitted in partial fulfillment of the requirements for the degree of Doctor of Education in the Department of Educational Research, Technology, and Leadership in the College of Education at the University of Central Florida Orlando, Florida.

Schwartz, S.H. (2006). Value orientations: Measurement, antecedents and consequences across nations. In: R. Jowell, C. Roberts, R. Fitzgerald, G. Eva (eds.), Measuring attitudes cross-nationally - lessons from the European Social Survey. London: Sage, 169-203.

Simpson, E. (1974). Moral development research: A case study of scientific cultural bias. Human Development, 17, 81-106.

Stanford Encyclopedia of Philosophy. (2021, 14 July). Deontological Ethics. Retrieved from: https://plato. stanford.edu/entries/ethics-deontological/

Stoian, C., Zaharia, R.M. (2012). CSR Development in Post-communist Economies: Employees' Expectations Regarding Corporate Socially Responsible Behaviour - the Case of Romania. Business Ethics: A European Review, 21(4), 380-401.

Struch, N., Schwartz, S.H., van der Kloot, W.A. (2002). Meanings of Basic Values for Women and Men: A Cross-Cultural Analysis. Personality and Social Psychology Bulletin, 28(1), 16-28.

Tapp, J.L., Kohlberg, L. (1971). Developing Senses of Law and Legal Justice. Journal of Social Issues, 27(2), 65-91.

Tatum, J.L., Foubert, J.D., Fuqua, D.R., Ray, C.M. (2013). The Relationship Between First Year College Men's Religious Affiliation and Their Moral Development. College Student Affairs Journal, 31(2), 101-110.

Traiser, S., Eighmy, M.A. (2011). Moral Development and Narcissism of Private and Public University Business Students. Journal of Business Ethics, 99, 325-334.

Weber, J. (1996). Welcoming Another CMD Instrument-the MES: But Don't Throw Out the MJI or DIT Just Yet! Commentary on The Empirical Performance of Cognitive Moral Development in Predicting Behavioral Intent D.P. Robin, G. Gordon, C. Jordan, \& R.E. Reidenbach 1996. Business Ethics Quarterly, 6(4), 517-522.

Marek Pawlak, prof. dr hab., Katolicki Uniwersytet Lubelski Jana Pawła II, Wydział Nauk Społecznych, Instytut Dziennikarstwa i Zarządzania, Katedra Zarządzania Przedsiębiorstwem. Jest profesorem nauk ekonomicznych, doktorem habilitowanym nauk ekonomicznych w zakresie dyscyplin o zarządzaniu. Od roku 2004 jest kierownikiem Katedry Zarządzania Przedsiębiorstwem KUL. Jego dorobek naukowy obejmuje osiem monografii autorskich, cztery artykuły w czasopismach posiadających impact factor. Wyniki swoich badań prezentował na konferencjach m.in. w Stanach Zjednoczonych, Indiach, Chinach, Hiszpanii, Włoszech. Jego zainteresowania naukowe dotyczą w ostatnich latach głównie etyki biznesu w szczególności systemów wartości i rozwoju moralnego.

Marek Pawlak, PhD, professor, the John Paul II Catholic University of Lublin, Faculty of Social Sciences, Institute of Journalism and Management, Department of Enterprise Management. He is a professor of economics, habilitated doctor of economics in the field of management. Since 2004 he has been the Head of the Department of Business Management at the John Paul II Catholic University of Lublin. His scientific achievements include eight monographs, four articles in journals with impact factor. He presented his research at conferences in the United States, India, China, Spain and Italy, among others. His research interests in recent years have mainly concerned business ethics, in particular value systems and moral development.

ORCID: https://orcid.org/0000-0002-5620-370X 
Adres/Address:

Katolicki Uniwersytet Lubelski Jana Pawła II

Wydział Nauk Społecznych, Instytut Dziennikarstwa i Zarządzania

Katedra Zarządzania Przedsiębiorstwem

Al. Racławickie 14

20-950 Lublin, Poland

e-mail: marek.pawlak@kul.pl 